\title{
LIVING-RELATED LIVER TRANSPLANT TO TREAT EPITHELIOID HEMANGIOENDOTHELIOMA - A CASE REPORT
}

\author{
Transplante hepático entre vivos no tratamento do hemangioendotelioma epitelióide do fígado - \\ Relato de caso
}

\begin{abstract}
Marcelo A. F. Ribeiro Jr.', Christian Evangelista Garcia², Telma Eugênio dos Santos ${ }^{3}$, Adavio de Oliveira e Silva ${ }^{3}$, Regina Leitão ${ }^{4}$, Cristiane Maria de Freitas Ribeiro 6 , Alexandre Zanchenko Fonseca ${ }^{5}$, Camila de Grande Cambiaghi6, Paulo Roberto de Arruda Zantut ${ }^{6}$, Luiz Augusto Carneiro D'Albuquerque ${ }^{7}$
\end{abstract}

\begin{abstract}
Introduction: Epithelioid hemangioendothelioma of liver is a rare, low-grade neoplasm of vascular origin that has an unpredictable malignant potential. It preferentially arises in soft tissues and bones, and seldom in the liver. Biologically, it trends to be multi-focal and often unresectable. Objective: The outcome of a patient submitted to a living-related liver transplant to treat epithelioid hemangioendothelioma of the liver. Case report: The reported case involves a 39-year old female patient with an immense epithelioid hemangioendothelioma of the liver, involving segments III, IV, V, VII, and VIIl. The prognostic to any kind of treatment was considered unfavorable, and the decision of submitting her to a liver transplant was made. It was suggested a living-related liver transplant. The donor was the patient's 36-year old brother, who donated his right liver lobe (segments V, VI, VII, VIII). The recipient's original liver was large, presenting very solid consistence and no node evidence. The transplant itself was performed using the conventional living-related liver transplantation technique. The recovery was good, and she was discharged from hospital on the 15th postoperative day using micophenolate mofetil, tacrolimus, and corticoid. Conclusion: Liver transplantation for epithelioid hemangioendothelioma of the liver can be performed with acceptable survival rate. The living related liver transplant opens a great perspective to that group of patients presenting liver tumors and who are unfeasible to wait for an organ on a waiting list.
\end{abstract}

Keywords: Hemangioendothelioma Epithelioid, Liver, Surgery, Transplantation.

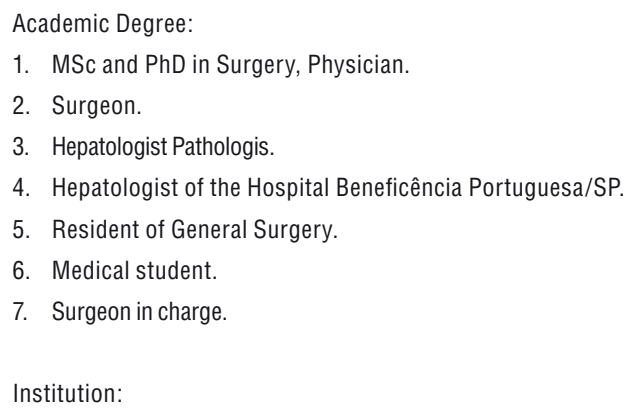

\section{INTRODUCTION}

Hepatic epithelioid hemangioendothelioma (HEH) is a rare, lowgrade tumor of vascular origin with a distinctive microscopic aspect. It has an unpredictable malignant potential. It is frequently misdiagnosed because its angiogenic nature is not often appreciated either radiographycally or microscopically. In 1984, authors reported for the first time 32 patients with such tumor in the liver. ${ }^{1}$

The current definition of such illness as a unique form of vascular lesion consisting of endothelial cells is based on the presence of immunohistochemical staining for Factor VIIIrelated antigen in the tumor.

It affects mostly women (61\%) in their third or fourth decade of life, and it can be associated to the use of oral contraceptives. It has been found in the liver, lungs, and several other soft tissues. ${ }^{2,3}$

\section{OBJECTIVE}

To report results of a living-related liver transplant performed as treatment of a patient with liver epithelioid hemangioendothelioma.

\section{PATIENT AND METHODS}

The 39-year-old woman complained of upper right quadrant abdominal pain, jaundice and pruritus. During her examinations, 
450 Marcelo A. F. Ribeiro Jr., Christian Evangelista Garcia, Telma Eugênio dos Santos, Adavio de Oliveira e Silva, Regina Leitão, Cristiane Maria de Freitas Ribeiro, Alexandre Zanchenko Fonseca, Camila de Grande Cambiaghi, Paulo Roberto de Arruda Zantut, Luiz Augusto Carneiro D'Albuquerque

the ultrasound examination suggested an immense liver mass. Biopsy of the hepatic lesion was interpreted as non-diagnostic. Upon the physical examination, patient presented hepatomegaly and jaundiced with no evidence of other diseases. Results of biochemical tests at admission were: total bilirrubin $=9,4$, direct fraction $=6,7, \mathrm{ggt}=853$, alkaline phosphatase $=342$ and albumin $=3,2$. Every sorological test as well as tumor markers were within normal values. The computed tomography and MRI scanning showed an immense tumor mass affecting segments III, IV, V, VII, and VIII compressing the biliary tree, with no signs of vascular invasion. The computed tomography of the chest and the brain scan were also performed, showing no evidence of tumor spreading. The consultant pathologist reviewed the case and by the immunohistochemical staining he concluded that it was a liver epithelioid hemangioendothelioma.

Due to the long waiting time on the transplantation list and after the surgical consultant's consideration that the tumor was not suitable for surgical resection, it was offered to the patient the possibility of a living-related liver transplant. Her brother, a 36 year-old healthy male, volunteered to be the donor. After the pertinent surgical and psychological examination, the patient was considered suitable for the donation and the transplantation was performed.

\section{RESULTS}

The recipient was submitted to a total hepatectomy; the liver contained a dominant multinodular, confluent, firm, white mass encompassing both lobes. There was no evidence of ascites or peritoneal spreading. Upon the histological examination, the tumor showed to be a small group of isolated neoplastic cells surrounded by a great amount of fibro-sclerotic stroma, which eventually obliterates the hepatic plates. The dense stromal matrix was particularly prominent at the acinar zone 3 or the central section of the hepatic lobules, with preservation of the architecture and portal triads. The donor surgery was a classic right hepatectomy (segments V, VI, VII, and VIII), preserving the middle hepatic vein. No complications occurred during the procedure, and the patient was discharged from the unit at the 7th postoperative day. The recipient had also no major complications, being discharged from the hospital after fifteen days.

\section{DISCUSSION}

It is very hard to choose the effective treatment in cases of this type of tumor, due to the unique neoplasm biology. Two main histological features typically characterize HEH: The presence of dendritic characteristic and/or epithelioid cells with evidence of vascular differentiation and identification of intracytoplasmic lumina containing red blood cells. The presence of stroma varying from myxomatous to densely fibrotic is typical. Variable degrees of fibrosis are also observed in every HEH tumor. ${ }^{3}$ Diagnosis is confirmed upon immunohistochemical evidence of an endothelialtype of tumor differentiation, as it was demonstrated by the presence of factor VIII-related antigen and cytokeratins. ${ }^{4}$

The prognosis is unpredictable; some patients survive for years with no treatment or liver transplant, whereas others succumb within months. ${ }^{5}$ The tumor is chemotherapy and irradiation resistant. Most reports found in the current literature recommend radical resection or liver transplantation ${ }^{6}$ as the best treatment whenever possible, despite a study comparing resection with transplants in patients with localized lesions showed poor results in the resection group, and more promising results using orthotopic liver transplantation: those treated with orthotopic transplantation had an overall survival rate of $71.3 \%$ at 5 years. ${ }^{7}$ Metastic disease is usually evident and found in $27 \%$ of cases. ${ }^{5}$ Metastasis to lymphonodes was not proved to influence the survival, and the investigators concluded that the favorable long-term results justified the orthotopic transplantation rather than resection. The curative treatment includes local resection and orthotopic liver transplant. Even treatment with Interferon 2 has been attempted, but the result remains unclear. Another study presented a single center experience related to the surgical treatment of four HEH patients. They were all female with a mean 39 years age, and the main symptoms were right upper quadrant abdominal pain, weight loss and weakness, similar to our patient. In three cases it was performed liver transplantation, and in one case, a right hemihepatectomy with partial resection of the diaphragm. One case of liver transplant was done using living donor, and it had a bile duct necrosis treated by bile duct revision. The follow-up of these cases varied from 13 to 151 months, and all patients are alive with no recurrence and no adjuvant or neo-adjuvant therapy of any kind was applied. ${ }^{8}$

Hepatic epithelioid hemangioendothelioma affects young adults that are usually in a good physical condition, and the transplant seems to be a good therapeutic option, especially with intra-hepatic dissemination, which contraindicates a partial hepatectomy and with no evidence of extra-hepatic extension. Interferon treatment of metastatic epithelioid hemangioendothelioma after liver transplantation may result in the symptom palliation and tumor reduction, but it also precipitates the graft rejection. ${ }^{9}$ The best time for the interferon therapy may be before the transplant. As the course of the HEH is not predictable in individual patients, the liver transplantation (LTx) could be even more aggressively considered as a potential treatment for patients with HEH. Correspondingly, in a recent review, early LTx was advocated in most patients with HEH. It could be shown that Ltx is indeed a valuable treatment even in extra-hepatic diseases..$^{10} \mathrm{~A}$ recent paper has pointed out that the immunosuppressant therapy may influence the outcome of this kind of tumor, suggesting that an approach consisting of basiliximab, corticoids, low doses of tracolimus, and the temporary administration of rapamycin may be safe and effective..$^{11}$ In our patient, the scheme used consists of tacrolimus, MMF and corticoids in low doses. On the other hand, a recently published study reported a 38 year-old female case treated using the association of interferon alpha $2 \mathrm{~B}$ and liver resection to avoid the LTx. The treatment protocol included daily interferon alpha $2 \mathrm{~B}$, nine weeks before and one week after the resection of the liver segments IV, VI, and VII, and according to the reports, the patient remains disease free after 3 years. ${ }^{12}$

\section{CONCLUSION}

Investigators concluded that the liver transplantation for epithelioid hemangioendothelioma of the liver can be performed with acceptable survival rates. The living-related liver transplant opens a great chance to this group of patients presenting liver tumors and who cannot wait for an organ on a waiting list. 


\section{RESUMO}

Introdução: Hemangioendotelioma epitelióide do fígado é uma neoplasia de origem vascular rara que tem um potencial maligno imprevisível. Cresce em partes moles e ossos, sendo incomum no fígado. Tende a ser multifocal e por isso irresecável. Objetivo: Relatar os resultados do tratamento de uma paciente com hemangioendotelioma epitelióide com transplante de fígado intervivos. Relato de caso: Uma paciente de 39 anos de idade com um imenso hemangioendotelioma epitelióide de fígado, acometendo os segmentos hepáticos III, IV, V, VII e VIII. Como a resposta a tratamentos mais conservadores foi considerada desfavorável, o transplante hepático foi indicado como conduta, sendo o transplante intervivos sugerido. O doador foi o seu irmão de 36 anos de idade, que doou o lobo hepático direito (segmentos V, VI, VII e VIII). O fígado da receptora era grande, de consistência endurecida e sem evidência de nódulos. A técnica utilizada no transplante foi a tradicional técnica de transplante intervivos. A paciente teve uma recuperação excelente, tendo alta hospitalar no 15o dia pós-operatório em uso de MMF, Tacrolimus e corticóides. Conclusão: Transplante em casos de hemangioendotelioma epitelióde de fígado pode ser realizado com altas chances de cura. O transplante intervivos é uma excelente opção para esse grupo de pacientes, que não podem esperar por um fígado na lista de espera pelo órgão

Palavras-chave: Hemangioendotelioma Epitelióide do fígado, Fígado, Cirurgia e Transplante.

\section{REFERENCES}

1. Ishak KG, Sesterheen IA, Goodman MZD, Rabin L, Stromeyer FW. Epithelioid hemangioendothelioma of the liver: A clinicopathologic and follow-up study of 32 cases. Hum Pathol. 1984;15:839-52.

2. Weiss SW, Enzinger FM. Epithelioid hemangioendothelioma : A vascular tumor often mistaken for a carcinoma. Cancer. 1982;50:970-81.

3. Makhlouf HR, Ishak KG, Goodman ZD - Epithelioid hemangioendothelioma of the liver: a clinicopathologic study of 137 cases. Cancer. 1999;85(3):562.

4. D'Annibale M, Piovanello P, Carlini P et al - Epithelioid hemangioendothelioma of the liver: case report and review of the literature. Transplant Proc. 2002;34(4):1248.

5. Dail DH, Liebow AA. Intravascular bronchioalveolar tumor (Abstr). Am J Pathol. 1975;78:6

6. Mehrabi A, Kashfi A, Pahlavan PS, StahlheberO, SchemmerP, Sauer Petal. Surgical therapy of epithelioid hemangioendotheliomas of the liver. Transplantation. 2004;78: 115-8.
7. Ben-Haim M, Roayaie S, Ye MQ, Thung SN, Emre S, Fishbein TA et al. Hepatic epithelioid hemangioendotheliomaP: Ressection or transplantation, wich and when? Liver Transpl Surg. 1999;5:526-31.

8. Mehrabi A; Kashfi A, Schemmer P etal-Surgical treatment of primary hepatic epithelioid hemangioendothelioma. Transplantation. 2005 Sep 27;80(suppl): S109-12.

9. Kayler LK, Merion RM, Arenas JD, et al - Epithelioid hemangioendothelioma of the liver disseminated to the peritoneum treated with liver transplantation and interferon alpha- $2 \mathrm{~B}$. Transplantation. 2002;74(1):128.

10. LerutJP, Orlando G, Sempoux C et al-Hepatic haemangioendothelioma in adults: excellent outcome following liver transplantation. Transpl Int. 2004;17(4):2002.

11. MuchaK, ForoncewiczB,ZieniewiczKetal-Patient with epithelioid hemangioendothelioma treated by transplantation: 3 year's observation. Transplant Proc. 2006;38:231-3.

12. Galvão FHF, Bakoni-Neto A, Machado MAC et al-Interferon alpha 2B and liver resection to treat multifocal hepatic epithelioid hemangioendothelioma: A relevant approach to avoid liver transplantation. Transplant Proc. 2005;37:4354-8. 